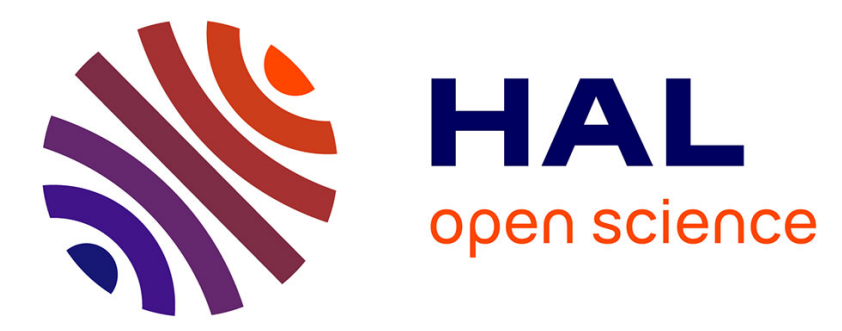

\title{
Monthly global irradiation on tilted planes : a simple correlation method and its validation
}

Bernard Bourges

\section{To cite this version:}

Bernard Bourges. Monthly global irradiation on tilted planes: a simple correlation method and its validation. BLOSS, W.H. and PFISTERER, F. Advances In Solar Energy Technology, Pergamon, pp.3811 - 3815, 1988, 978-0-08-034315-0. 10.1016/B978-0-08-034315-0.50703-5 . hal-00949142

\section{HAL Id: hal-00949142 \\ https://hal.science/hal-00949142}

Submitted on 23 May 2014

HAL is a multi-disciplinary open access archive for the deposit and dissemination of scientific research documents, whether they are published or not. The documents may come from teaching and research institutions in France or abroad, or from public or private research centers.
L'archive ouverte pluridisciplinaire HAL, est destinée au dépôt et à la diffusion de documents scientifiques de niveau recherche, publiés ou non, émanant des établissements d'enseignement et de recherche français ou étrangers, des laboratoires publics ou privés. 
ISES Solar World Bongrass. Hamburg 1987

"Advances in Solar Evergy Technology" Blose and Pfiturer "Pergaman , Vol, \& 3811

MONIALY GLOBAL IRRADIATION ON TILTED PLANES:

A SIMPLE CORRELATION METHOD AND ITS VALIDATION

Bernand BCURGES, Consultant

6, rue de 1'Armor, 35760 St-Grégoire (France)

AESTRACT

This paper presents a simple correlation for the computation of monthly global solar irradiation on tilted surfaces, facing due south. The conversion factor, $R$, from the horizontal plane to the tilted plane, is considered: it has been established from the Solar Radiation European Atlas data (computed by Pr. Page's algorithm) R is linearly correlated to the monthly clearness index, Kt. The correlation slope depends on the month, the latitude and the int angle. This set of correlations fits the European Atlas Data within $2 \%$ in sumer and $5 \%$ in winter (tilt ang. (60deg), within 5 to $10 \%$ for South-vertion are also presented locations are also presented. In some cases, there is a slight systematic underresults Bracknell, Valentia).

KEYHORDS

Solar radiation; tilted'plane; linear correlation; validation; measurements.

\section{INIRODUCTION}

This paper presents a simple method of estimating the monthly global irradiation on a tilted plane facing due South from the irradiation value on a horizontal plane. This latter value is available for a number of locations all over the world or may be easily computed by using Angstrom type correlations. based on sunshine hours. But the end user is generally interested in the value for a specific inclined surface, in onder to design a solar thermal or photovoltaic system for example.

THE R-CORREIATION

Let us consider the conversion factor, $R$, from horizontal plane irradiation to tilted plane irradiation Ht during a given month
$\mathrm{R}=\mathrm{Ht} / \mathrm{H}$

A linear correlation between $\mathrm{R}$ and the clearness index Kt has been investigated in the form

$R=(1+\cos s) / 2+r,(1-\cos s) / 2+b . K t$

where $s$ is the slope of the surface, and $r$, the ground albedo.

This form is suggested by the usual relationship of $R$ assuming the diffuse sky radiation $D$ to be isotropic (Rb is the consip of $R$ assuming the diffuse diation)

$R=(1-D / H) \cdot R b+D / H \cdot(1+\cos s) / 2+I(1-\cos s) / 2$

The additional assumption of $\mathrm{D} / \mathrm{H}$ being a linear function of $\mathrm{Kt}$ leads to eqn 2. This also suggests that the slope of the correlation line, $b$, depends on the tilt angle, the month and the latitude.

Tilted plane data from the European Atlas (Palz, 1984a, 1984b) has been used. The values are computed rather than (Palz, 1984a, 1984b) has been algorithm (Page, 1986) which accounts tor the diffuse sky a complete an-isotropy.

The correlation between $R$ and $K t$ has been established for three tilt angles (30, 60 and 90 deg.) and all the months of the year. The slope of the correlation straight-line, $b$, is a quadratic function of the geographical latitude. This can be sumarized in a set of charts (e.g. Fig. l) giving $R$ vs Kt for a given tilt angle and latitude. A polynomial interpolation is proposed in order to generalize the results to cover any tilt angle. Complete results have been published in an earlier paper (Bourges, 1987). The accuracy of this method, with respect to the original European Atlas data used for its development, can be characterized by the relative standard- deviation of errors (Table 1) (i.e. S.D, of the ratio Rcomputed /

This standard- deviation is dependent on slope and month. The best accuracy is obtained in summer at low slopes ( 30 deg.) where standard-deviation is equal to $0.5 \%$; the error increases with slope $1.5 \%$ to $2.0 \%$ for a vertical surface for the same sumer month) and becomes the greatest during winter
months (2\% to $3 \%$ at $30 \mathrm{deg} ., 3 \%$ to $5 \%$ at 90 deg.).

Table 1 Relative Standard-Deviation of Errors $(x)$ of the R-correlation

$\begin{array}{lllllllllllll}\text { Month } & 1 & 2 & 3 & 4 & 5 & 6 & 7 & 8 & 9 & 10 & 11 & 12\end{array}$

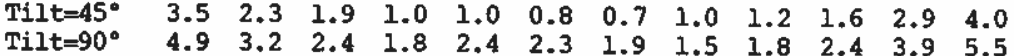

Fig. 1: Example of R-charts providing the conversion factor for tilted plane, $R$, as a function of the clearness index, $\mathrm{Kt}$.

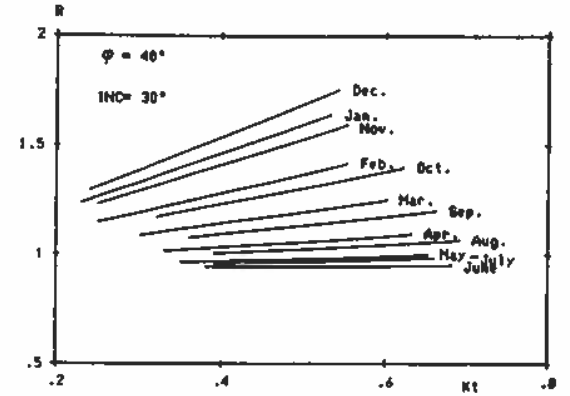


VALIDATION

Data used for the development of the present R-correlations consists of computed rather than measured values. Although the computation method (Page, 1986) is based on a number of experimental results, it seems to be necessary to validate the present correlation with respect to measured irradiation values on that is available for a sample of location Table 2.

Table 2 Experimental Data used for the present Validation Albedo values of 0.2 are estimated.

\begin{tabular}{lrlrrrrr}
\hline Location & Latit. & Country & Tiltang. & Period & Days & Alb. & Source \\
\hline Albany & $42.7^{\circ} \mathrm{N}$ & U.S.A. & $43-90^{\circ}$ & $1980-81$ & 500 & 0.0 & A.S.R.C. (1983) \\
Carpentras & $44.1^{\circ} \mathrm{N}$ & France & $45-90^{\circ}$ & $1979-81$ & 766 & 0.0 & Dir. de 1a Météo. \\
Ispra & $45.8^{\circ} \mathrm{N}$ & Italy & $45-90^{\circ}$ & $1980-85$ & 2000 & 0.2 & Boliini (1986) \\
Geneva & $46.2^{\circ} \mathrm{N}$ & Switz. & $45-90^{\circ}$ & $1979-82$ & 1095 & 0.2 & Ineichen (1983) \\
Trappes & $48.8^{\circ} \mathrm{N}$ & France & $45-90^{\circ}$ & $1979-81$ & 500 & 0.0 & Dir. de la Météo. \\
Bracknell & $51.4^{\circ} \mathrm{N}$ & U.K. & $90^{\circ}$ & $1966-75$ & 3000 & 0.0 & U.K. Met. Office \\
Valentia & $51.9^{\circ} \mathrm{N}$ & Irel. & $90^{\circ}$ & $1976-78$ & 730 & 0.2 & Irish Met. Serv. \\
\hline
\end{tabular}

RESULTS

The results of the comparison between measured irradiation values and computed values using the former R-correlations are presented in Table 3 and fig.2. They have to be analyzed with respect to the scattering of the of the values (95\%) must be in the range $t 2.5$ s.D. (Confiance interval the gaussian assuntion) the gaussian assustion)

Results are quite satisfactory and consistent with this assumption for a few locations: Bracknell, Valentia and Geneva (Yearly average irradiation can be estimated in these cases with an uncertainty range of $1 x_{1}$.

Systematic significant underestimations are observed in the other data (Albany, Carpentras, Ispra and Trappes) ( 3 to $8 \%$ on a yearly level) whatever the tilt angle. Significant overestimations are only observed at Geneva on the vertical surface during summer months $(7 \%)$.

DISCUSSION

Several problems may explain the observed discrepancies between measured and computed values. They are discussed below.

The ground albedo is not known exactly at some locations. Furthermore seasonal variations have been observed, for example smaller values at high solar altitude (Ineichen, 1983). The influence of this factor is small in the case of a 45-degree inclination, but it becomes significant for vertical surfaces. A 0.10 absolute error on this factor introduces relative errors in the computation of the irradiation on the surface within $3 \%$ (winter) and $10 \%$ (summer). This fact probably explains the overestimation of the summer months in Geneva and perhaps a fraction of the discrepancy observed at Ispra.
This problem is irrelevant at the other locations (Trappes, Carpentras and Albany), where there is no ground-reflected radiation (either eliminated by an hich disk or measured separately and subtracted).

cases) has to be considered because from 10-year averages. This fact may explain soms have been established (e. august at Trappes only 33 ans of systematic trend. This has been checked in the following averages have been computed at Carpentras from hour following way: 10-year and beam radiation com tilted surfaces is an algorithm by Perez (1986) which has been shown to be the most accurate for this purpose (Bourges, 1986) on a long-term basis the yearly error could be reauced to about $-5 \%$, unt still remains ouite significant (Table 4).

Measurement errors could also be considered in the analysis but cannot be

seriously upheld as a general explanation for these 3 locations.

The cause should probably be determined from the correlations themselves, algorithm.

CONCLUSION

A set of R-correlations has been presented. It provides a simple computation method for monthly irradiations on tilted planes (facing South) from the corresponding irradiation on a horizontal plane. The comparison with measured data leads to a general accuracy of about $5 \%$, with a tendency to underestimate at some locations. Relative errors are the greatest during winter months and for vertical surfaces (10\%). Nevertheless this accuracy may be considered as satisfactory, given the simplicity of the method and the various causes of errors in lts application: uncertainties as to the irradiation on a horizontal plane and as to the albedo, and year-to-year variations.

REFERENCES

A.S.R.C. (1983). Quarterly Solar Climatolog. Summary. St. Univ. of New-York. BOLLINI, G. and $\overline{c o-w . ~(1986) . ~} 27$ Annuario Meteo, 1985 di Ispra . C.C.E., Report EUR 10570 IT (published yearly).

BOURGES, B. (1986). Le calcul de l'éclairement solaire sur plans inclinés. LA MOETEOROLOGIE, 7 éme Série, No 11

Nass, B. computation of monthly solar global irradiation on tilted planes. Int. J. Sol. Energy, 5, 171-184. se de Doctorat. Université dé Genève. PAGE, J.K. (1986). Prediction of Solar Radiation on Inclined Surfaces. REIDEL Dordrecht, $459 \mathrm{p}$.

PALZ, W. and co-workers (1984a). European Solar Radiation Atlas. Volume 1: Horizontal surfaces. Verlag TuV Rheinland, Koln.

ALZ, W. and co-workers (1984b). European Solar Radiation Atlas. Volume 2: Inclined Surfaces. Verlag Tuv Rheinland, Koln.

EREZ, R. and co-workers (1986). INIERSOL 85, MONIREAL, Vol.4, pp. 2498-2502. PERGAMON, 
Table 3 Daily average global irradiation on tilted planes (MJ/m2). Comparison of measured and computed values

GENEVA $s=45 \mathrm{deg}$. GENEVA $s=90 \mathrm{deg}$. Month Jan. Apr. Jul. Oct. Year Jan. Apr. Jul. Oct. Year $\begin{array}{lrlllllllll}H \text { meas. } & 5.0 & 19.5 & 19.3 & 10.7 & 13.4 & 4.3 & 12.4 & 10.0 & 8.6 & 8.9\end{array}$ $\begin{array}{lrrrrrrrrrr}\text { H calc. } & 5.1 & 19.4 & 19.5 & 10.3 & 13.2 & 4.6 & 12.4 & 10.6 & 8.5 & 9.0 \\ \text { Diff. }(\%) & 1 & -1 & 1 & -4 & -1 & 7 & 0 & 7 & -1 & 1\end{array}$

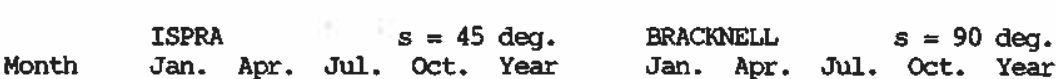
$\begin{array}{lrllllrrrrr}\text { Month } & \text { Jan.: Apr. Jul. } & \text { Oct. } & \text { Year } & \text { Jan. } & \text { Apr. } & \text { Jul. } & \text { Oct. } & \text { Year } \\ \text { H meas. } & 9.4 & 17.4 & 20.0 & 12.6 & 14.1 & 2.9 & 7.6 & 7.6 & 6.8 & 6.4\end{array}$

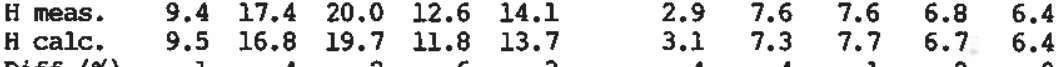

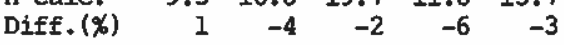
CARPENIRAS $s=45$ deg. Month Jan. Apr. Jul. Oct. Year Jan. Apr. Jul. Oct. Year

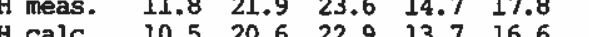
$\begin{array}{lrrrrrrrrrr}\text { Calc. } & 10.5 & 20.6 & 22.9 & 13.7 & 16.6 & 9.7 & 11.1 & 9.3 & 10.7 & 10.1 \\ \text { Diff. }_{(8)} & -11 & -6 & -3 & -7 & -6 & -13 & -7 & -5 & -7 & -9\end{array}$ TRAPPES $s=45 \mathrm{deg}$.

Month Jan. Apr. Jul. Oct. Year

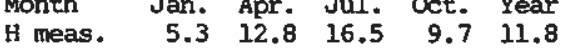
$\begin{array}{llllll}H \text { calc. } & 4.6 & 12.2 & 15.8 & 8.7 & 11.0\end{array}$

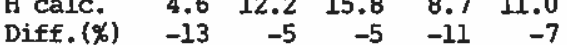

\section{TRAPPES}

$s=90 \mathrm{deg}$

Jan. Apr. Jul. Oct. Year $\begin{array}{lllll}4.7 & 7.5 & 8.1 & 7.8 & 7.6\end{array}$

$=43$ deg.

Month Jan. Apr. Jul. Oct. Year

$H$ meas. 11.1 15.5 $19.1 \quad 12.914 .6$

$\begin{array}{lrrrrr}H \text { calc. } & 10.7 & 14.5 & 18.2 & 11.6 & 13.8 \\ & -4 & -7 & -5 & -10 & -5\end{array}$

$$
\begin{array}{rrrrr}
\multicolumn{2}{c}{\text { VALENTIA }} & \multicolumn{3}{c}{s=90} \\
\text { Jan. } & \text { Apr. } & \text { Jul. } & \text { Oct. } & \text { Year } \\
4.0 & 10.6 & 9.1 & 7.1 & 7.4 \\
3.9 & 10.5 & 9.2 & 6.8 & 7.3 \\
-4 & -2 & 1 & -4 & -1
\end{array}
$$

Table 4 Idem Table 3. "Measured" values are actually computed using Perez'

\section{CARPENTRAS $s=45$ deg.}

Month Jan. Apr. Jul. Oct. Year

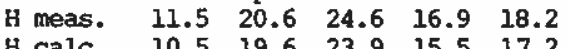

$\begin{array}{lrrrrr}\text { H calc. } & 10.5 & 19.6 & 23.9 & 15.5 & 17.2 \\ \text { Diff. }(\%) & -8 & -5 & -3 & -9 & -5\end{array}$

CARPENIRAS

$s=90 \mathrm{deg}$.

Jan. Apr. Jul. Oct. Year

$\begin{array}{lllll}11.1 & 12.7 & 12.4 & 14.2 & 12.6\end{array}$

$\begin{array}{rrrrr}10.1 & 12.2 & 11.9 & 13.0 & 11.8 \\ -9 & -4 & -4 & -9 & -6\end{array}$

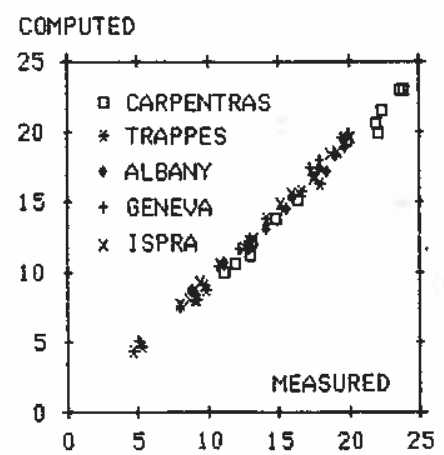

Fig. 2: Measured vs computed values of monthly irradiations (MJ/m2/day) on a tilted plane (slope $=45 \mathrm{deg}$. ) at various locations. 